\section{Preparation of particle-reinforced mullite composite ceramic materials using kaolin and IG-017 bio-origin additives}

EMESE KUROVICS - Institute of Ceramics and Polymer Engineering, University of Miskolc, Hungary fememese@uni-miskolc.hu

OLGA B. KOTOVA - Institute of Geology, Komi Science Center, Ural Branch of the Russian Academy of Sciences, Russian Federation - kotova@geo.komisc.ru

LÁsZló A. GÖMZE - Institute of Ceramics and Polymer Engineering, University of Miskolc, Hungary, IGREX Engineering Service Ltd, · femgomze@uni-miskolc.hu

DMITRY A. SHUSHKOV - Institute of Geology, Komi Science Center, Ural Branch of the Russian Academy of Sciences, Russian Federation - dashushkov@geo.komisc.ru

GRIGORIY V. IGNATIEV - Institute of Geology, Komi Science Center, Ural Branch of the Russian Academy of Sciences, Russian Federation • ignatiev.grigoriy@gmail.com

PetR A. SITNIKOV - Institute of Chemistry, Komi Science Center, Ural Branch of the Russian Academy of Sciences, Russian Federation • sitnikov-pa@mail.ru

YURI I. RYABKOV - Institute of Chemistry, Komi Science Center, Ural Branch of the Russian Academy of Sciences, Russian Federation • ryab2012@gmail.com

IRINA N. VASENEVA - Institute of Chemistry, Komi Science Center, Ural Branch of the Russian Academy of Sciences, Russian Federation • ir_vaseneva@mail.ru

LuDMILA N. GÖMZE - Igrex Engineering Service Ltd., Hungary • igrex2009@yandex.ru

Érkezett: 2019. 06. 26. - Received: 26. 06. 2019. - https://doi.org/10.14382/epitoanyag-jsbcm.2019.20

\section{Abstract}

In this research work, the possibilities of producing advanced ceramics from traditional, relatively inexpensive raw materials were studied. Powder mixtures from kaolinite and IG-017 bio-original additive were milled and uniaxially pressed to pellets, then pre-sintered in the electric kiln under oxidation and oxygen-free atmosphere at $1250^{\circ} \mathrm{C}$. The pre-sintered specimens were then further sintered in nitrogen gas at $1600^{\circ} \mathrm{C}$. The produced specimens were tested on composition, microstructures and morphologies using several characterization techniques including X-ray diffraction (XRD), scanning electron microscopy (SEM) and energy dispersive spectroscopy (EDAX). The conducted experiments by the authors have shown that it is possible from traditional kaolinite to develop technical ceramic specimens with increased physical and mechanical properties based on formed amorphous phases, mullite crystals, micro and nano carbon fibers. Keywords: carbonization, ceramic, composition, microstructure, mullite, sintering Kulcsszavak: karbonizáció, kerámia, összetétel, mikroszerkezet, mullit, szinterezés

\section{Introduction}

In recent years, there is a huge demand in many industries for new low-density materials with enhanced physical, electrical, magnetic, mechanical, thermal or chemical properties [1-34]. Thanks to these continuously increased requirements, more and more ceramic materials and ceramic-based composites are being developed and used in various fields of industry and technology [35-46]. Mullite is a stable intermediate phase under atmospheric pressure in the $\mathrm{Al}_{2} \mathrm{O}_{3}-\mathrm{SiO}_{2}$ system (Fig. 1) [47]. Despite the rare occurrence of mullite as mineral, the sintered mullite crystals are playing an important role both in traditional and modern technical ceramics. Fig. 1 shows how the various crystals and phases are depending on the temperature and also reveals that pure mullite $\left(3 \mathrm{Al}_{2} \mathrm{O}_{3}-2 \mathrm{SiO}_{2}\right)$ melts at $1870{ }^{\circ} \mathrm{C}$. Generally, at normal (atmospheric) pressure mullite crystals are capable to incorporate several transition metal cations and other foreign atoms into their structures depending on sintering environment and temperature [48-50].
Emese KUROVICS,

is graduated from the University of Miskolc, Department of Ceramics and Silicate Engineering as a material engineer, where she continues her study as PhD student under supervision of Prof. L. A. Gömze.

Olga B. KOTOVA, is professor and Head of Laboratory of Technology of Mineral Raw, Institute of Geology Komi Science Center, Ural Branch of the Russian Academy of Sciences. Author and co-author of 4 patents and more than 150 scientific articles. Vice-president of International Commission on Applied Mineralogy (IMA-ICAM). Member of Russian Mineralogical Society.

László A. GÖMZE, is establisher and professor of the Department of Ceramics and Silicate Engineering in the University of Miskolc, Hungary. He is author or co-author of 2 patents, 6 books and more than 300 scientific papers.

Dmitry A. SHUSHKOV, Researcher of Laboratory of Technology of Mineral Raw, Institute of Geology, Komi Science Center, Ural Branch of the Russian Academy of Sciences. Author and co-author of 2 patents and more than 40 scientific articles. Russian Mineralogical Society.

Grigoriy V. IGNATIEV, Junior researcher of Laboratory of Chemistry of Mineral Raw, Institute of Geology, Komi Science Center, Ural Branch of the Russian Academy of Sciences. He actually continues his studies as PhD student

Petr A. SITNIKOV, head of the Laboratory of Ultradispersed Systems of the Institute of Chemistry, Komi Science Center, Ural Branch of the Russian Academy of Sciences, associate professor. His research was published in 1 book, more than 50 scientific articles, 8 patents. The participant of many international conferences and symposia. Member of the Russian Chemical Society named after D.I. Mendeleev.

Yuri I. RYABKOV, head of the Department of "Chemistry and Physics of Materials" of the Institute of Chemistry, Komi Science Center. Ural Branch of the Russian Academy of Sciences, Ph.D. Specialist in the field of materials science of ceramic and ceramic matrix composites based on oxides and carbides. $\mathrm{He}$ is the author and co-author of more than 100 articles, 6 monographs, 21 patents. Member of the Russian Chemical Society named after D.I. Mendeleev.

Irina N. VASENEVA, Junior Researcher, Institute of Chemistry, Komi Science Center, Ural Branch of the Russian Academy of Sciences. Specialist in the field of physico-chemical bases of creating composite materials. She is a co-author of more than 20 articles, 11 patents. Member of the Russian Chemical Society named after D.I. Mendeleev.

Ludmila N. GÖMZE, is MSc (civil engineer), managing director of the IGREX Engineering Ltd. Author or co-author more than 30 scientific papers. 


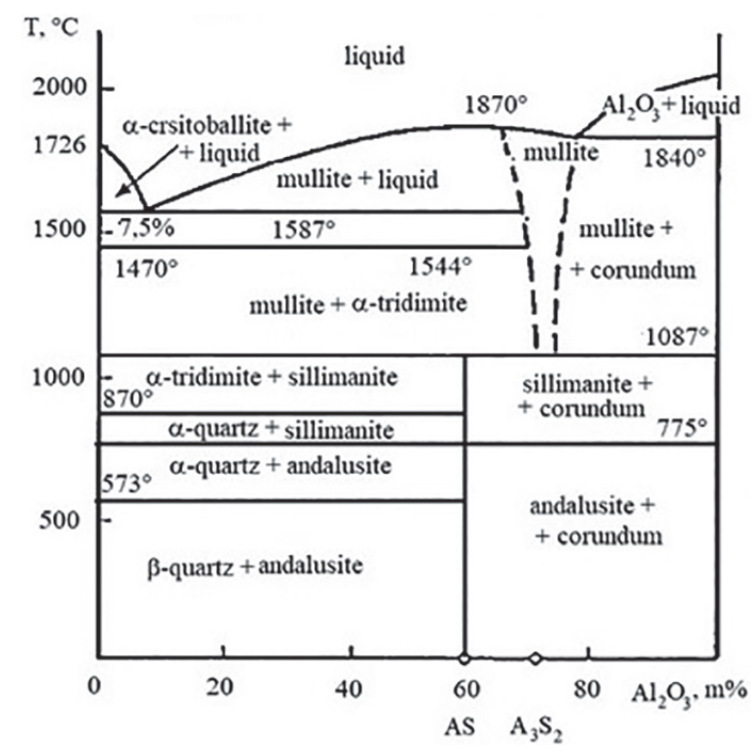

Fig. $1 \mathrm{SiO}-\mathrm{Al}_{2} \mathrm{O}_{3}$ phase diagram [47] (Taken from $\mathrm{N} M$ Bobkova: Fizicheskaya Himiya Tugoplavkih Nemetallicheskih i Silicatnyh Materialov, 2007)

1. ábra $\mathrm{SiO}_{2}-\mathrm{Al}_{2} \mathrm{O}_{3}$ fázisdiagram [47] (Âtvéve: $\mathrm{N}$ M Bobkova: Fizicheskaya Himiya Tugoplavkih Nemetallicheskih i Silicatnyh Materialov, 2007)

Generally, non-oxide technical ceramics and nitride ceramics have a much higher surface hardness and compression strength than metals and metal alloys or oxide ceramics, but their production costs are usually very expensive [51]. Nitridebased ( $\mathrm{SiAlON}$ or $\mathrm{Si}_{3} \mathrm{~N}_{4}$ ) materials are considered as significant and attractive structural ceramics/refractories because of their excellent properties, like high mechanical properties (e.g., strength, hardness, toughness), chemical inertness, good corrosion resistance and outstanding thermal resistance.

Silicon nitride is a non-natural mineral that needs to be synthesized by different methods [52-54]. The easiest way to produce silicon nitride from kaolin or other clay minerals is through carbothermal reduction and nitridation. The following reaction equations show the steps in which silicon carbide, silicon oxynitride, silicon nitride, and sialons are formed during the process [53-56].

1. Decomposition of kaolin at a temperature of $450{ }^{\circ} \mathrm{C}$

$\mathrm{Al}_{2} \mathrm{O}_{3} \cdot 2 \mathrm{SiO}_{2} \cdot 2 \mathrm{H}_{2} \mathrm{O} \rightarrow \mathrm{Al}_{2} \mathrm{O}_{3} \cdot 2 \mathrm{SiO}_{2}$ (metakaolin) $+2 \mathrm{H}_{2} \mathrm{O}$ (vapor) (1)

2. Formation of mullite $\left(3 \mathrm{Al}_{2} \mathrm{O}_{3} \cdot 2 \mathrm{SiO}_{2}\right)$ as decompound of metakaolin at a temperature at $1087^{\circ} \mathrm{C}$

$3\left(\mathrm{Al}_{2} \mathrm{O}_{3} \cdot 2 \mathrm{SiO}_{2}\right) \rightarrow 3 \mathrm{Al}_{2} \mathrm{O}_{3} \cdot 2 \mathrm{SiO}_{2}+4 \mathrm{SiO}_{2}$ (amorphous)

While the temperature raises up to $1360^{\circ} \mathrm{C}$, amorphous $\mathrm{SiO}_{2}$ begins to transform into crystalline $\mathrm{SiO}_{2}$.

Carbothermal reduction and simultaneous nitridation occur at a temperature above $1400^{\circ} \mathrm{C}$

$\mathrm{SiO}_{2}+\mathrm{C} \rightarrow \mathrm{SiO}(\mathrm{g})+\mathrm{CO}(\mathrm{g})$

$3 \mathrm{Al}_{2} \mathrm{O}_{3} \cdot 2 \mathrm{SiO}_{2}+2 \mathrm{C} \rightarrow 3 \mathrm{Al}_{2} \mathrm{O}_{3} \cdot 2 \mathrm{SiO}(\mathrm{g})+2 \mathrm{CO}(\mathrm{g})$

3. Formation of silicon oxynitrides takes place progressively in environment richer in nitrogen under the reducing influence of the carbon

$3 \mathrm{SiO}_{2}+3 \mathrm{C}+\mathrm{N}_{2} \rightarrow \mathrm{Si}_{2} \mathrm{~N}_{2} \mathrm{O}$

$2 \mathrm{SiO}(\mathrm{g})+\mathrm{C}+\mathrm{N}_{2} \rightarrow \mathrm{Si}_{2} \mathrm{~N}_{2} \mathrm{O}+\mathrm{CO}(\mathrm{g})$

4. Formation of $\chi$-phase sialon and $\beta$ '-sialon from mullite

$3\left(\mathrm{Al}_{2} \mathrm{O}_{3} \cdot 2 \mathrm{SiO}_{2}\right)$ (mullite) $+12 \mathrm{C}+\mathrm{N}_{2} \rightarrow$

$\mathrm{Si}_{3} \mathrm{Al}_{6} \mathrm{O}_{12} \mathrm{~N}_{5}$ ( $\mathrm{X}$ - phase sialon) $+6 \mathrm{AlN}+\mathrm{SiO}_{2}+12 \mathrm{C}$

$\mathrm{Si}_{3} \mathrm{Al}_{6} \mathrm{O}_{12} \mathrm{~N}_{5}+3 \mathrm{~N}_{2}+9 \mathrm{C} \rightarrow \mathrm{Si}_{3} \mathrm{Al}_{3} \mathrm{O}_{3} \mathrm{~N}_{5}\left(\beta^{\prime}-\right.$ sialon $)+2 \mathrm{AlN}+9 \mathrm{CO}(8)$
5. Formation of $\mathrm{SiC}$

$\mathrm{SiO}_{2}+2 \mathrm{C} \rightarrow \mathrm{SiC}+\mathrm{CO}_{2}(\mathrm{~g})$

6. Formation of $\mathrm{Si}_{3} \mathrm{~N}_{4}$

$3 \mathrm{SiO}_{2}+6 \mathrm{C}+2 \mathrm{~N}_{2} \rightarrow \mathrm{Si}_{3} \mathrm{~N}_{4}+6 \mathrm{CO}$

The Si-N bonds are formed at $1200^{\circ} \mathrm{C}$ in the presence of carbon. These bonds are progressively formed in $\mathrm{N}$-rich environment and lead to a continuous formation of silicon oxynitride compositions. Usually, these bonds are not detected by XRD but appear later in the reaction, when crystalline silicon oxynitride persists throughout the reaction and possibly containing a little amount of $\mathrm{Al}$ (like $\mathrm{O}$-sialon and $\mathrm{x}$-phase sialon). After the destruction of the mullite, the Si-O bonds survive and remain throughout the reaction, especially in the kaolinite starting material. Later in the reaction, $\mathrm{Si}-\mathrm{C}$ bonds are formed. The created $\mathrm{SiC}$ phase behaves more like a secondary product than a transitory intermediate [54-56].

Based on the studied literatures, it can be said that mullite or mullite containment taken from kaolinite can be successfully used as a matrix material for silicon nitride particles or whiskers reinforced ceramic composites. $\mathrm{Si}_{3} \mathrm{~N}_{4}$ particles and whiskers can considerably enhance the mechanical strengths and toughness of both kaolinite and mullite based ceramic composites. Using conventional kaolinite or other types of clay minerals as starting materials, different micro and nano-size reinforcement materials can be produced like, $\mathrm{SiC}, \mathrm{Si}_{3} \mathrm{~N}_{4}, \mathrm{Si}_{2} \mathrm{ON}_{2}$ or $\mathrm{SiAlON}$ through carbothermal reduction and nitridation.

The aims of this work are to develop ceramic composites material with superior physical and mechanical properties using relatively inexpensive processing technology and raw materials like conventional kaolinite or other clay minerals. In this work, the authors present a part of their research on the production of carbon-containing ceramics using kaolin and a biological additive. Further these produced ceramic composite could be a potential candidate for many applications showing better mechanical properties.

\section{Materials and Experiments}

Particle-reinforced mullite composite ceramics were prepared via carbothermal reduction and nitridation techniques, commercial kaolinite powders KKA-MB and IG017 refined bio-original additives developed and produced by IGREX Ltd. were used as starting raw materials. Stochiometric amount of these ceramic powders were weighted using 6 different mixtures compositions as shown in Table 1. The prepared ceramic mixtures were well milled in a laboratory ball mill for 20 minutes in the speed of $200 \mathrm{rpm}$. The milled powders then uniaxially compacted at $150 \mathrm{MPa}$ pressures to produce 24 cylindrical disc specimens with diameters of 20 $\mathrm{mm}$ for each mixture. The filling weights of specimens were 8 grams in each case. After compacting, half of the specimens were pre-sintered in normal (oxidation) atmosphere and the other half of the specimens were pre-sintered in an oxygenfree atmosphere. In both cases, the maximum pre-sintering temperatures were $1250{ }^{\circ} \mathrm{C}$. After these, the pre-sintered specimens were well studied and later they were burned at $1600{ }^{\circ} \mathrm{C}$ using nitrogen gas in the high-temperature kiln. Fig. 2 shows the sintered specimens. 


\begin{tabular}{lcc} 
Mixture & Kaolinite & IG-017 \\
I. & 85 & 15 \\
\hline II. & 75 & 25 \\
\hline III & 65 & 35 \\
\hline IV. & 55 & 45 \\
\hline V. & 45 & 55 \\
\hline VI. & 35 & 65
\end{tabular}

Table 1. The volumetric relationship between components in $m \%$ 2. táblázat Az EDAX vizsgálat során kapott elemi összetétel

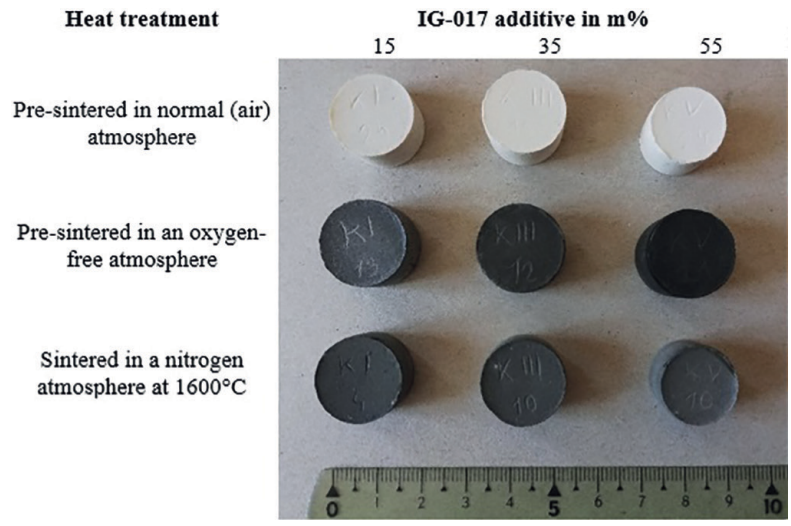

Fig. 2 The specimens after the sintering process

2. ábra A szinterelt próbatestek

\section{Results and discussions}

Part of the authors have already shown in their earlier work some properties of the pre-sintered specimens, like volume shrinkage, weight losses, density, porosity and microstructure [57]. In this work are shown how the properties change due to sintering the specimens at a high sintering temperature $\left(1600^{\circ} \mathrm{C}\right)$ in nitrogen gas. During pre-sintering of the specimens, firstly, drying of the samples takes place, followed by removal of the crystalline waters from kaolinite structure at approximately $450^{\circ} \mathrm{C}$, parallelly gasification of the IG-017 additives occurs. Pre-sintering kaolinite at a temperature of $1250^{\circ} \mathrm{C}$ is high enough for the formation of mullite crystal phases and free $\mathrm{SiO}_{2}$ components. Some of the specimens from each mixture were further sintered at $1600^{\circ} \mathrm{C}$, where $\mathrm{SiC}$ and $\mathrm{Si}_{3} \mathrm{~N}_{4}$ can be formed in the ceramic product. Figs. 3 and 4 show the volume shrinkages and weight losses of the sintered samples.

Fig. 3 compares the volume shrinkage of the heat-treatmed ceramic products to that of the pre-sintered and crude product volumes. Oxygen deficient pre-sintered ceramic specimens exhibit higher shrinkage. In contrast, the total volume shrinkages of the two type of pre-sintered specimens were almost the same.

Fig. 4 shows the weight loss of the specimens fired at $1600^{\circ} \mathrm{C}$ in an Oxygen atmosphere and Oxygen-free environment. In the case of the use of a larger amount of bio-original additive, the weight of the oxidation pre-sintered samples is increased, this could be possibly due to the incorporation of Nitrogen gas into the samples. In the case of oxygen-free pre-sintered specimens, some of the carbon remaining in the material structure is discharged during sintering at $1600^{\circ} \mathrm{C}$. Examination of the microstructure and elemental composition of the samples was done by scanning electron microscopy (SEM).

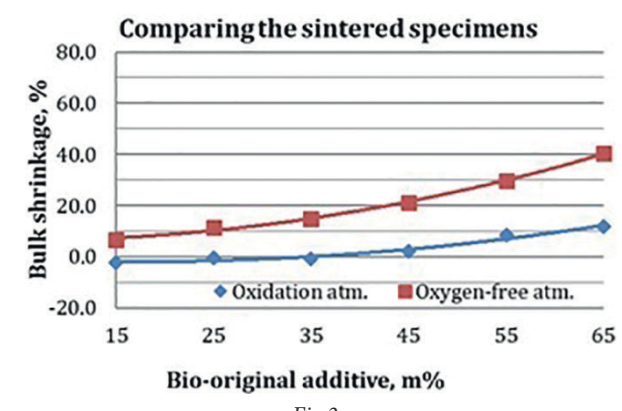

Fig $3 a$

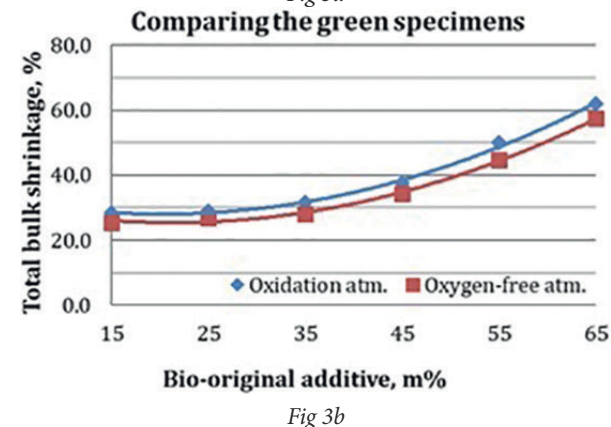

Fig. 3 The volume shrinkage after sintered the specimens at $1600{ }^{\circ} \mathrm{C}$ 3. ábra A térfogati zsugorodás az $1600^{\circ} \mathrm{C}$-os szinterelés után

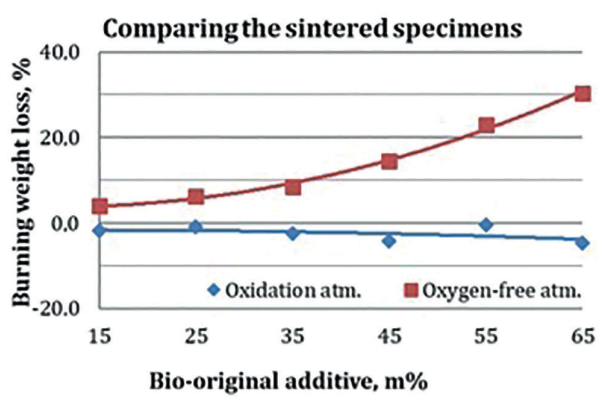

Fig $4 a$

Comparing the green specimens

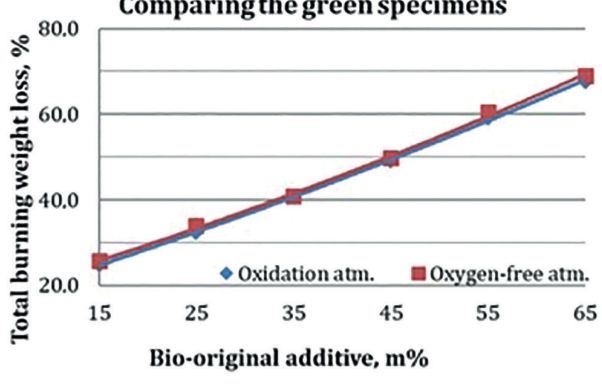

Fig $4 b$

Fig. 4 The weight losses after sintered the specimens at $1600^{\circ} \mathrm{C}$

4. ábra A tömegveszteség az $1600^{\circ} \mathrm{C}$-os szinterelés után

Fig. 5 shows the outer surface and breaking surface of a specimen made with $15 \mathrm{~m} \%$ bio-additive pre-sintered in an oxidation atmosphere and then heat-treated in nitrogen at $1600^{\circ} \mathrm{C}$. It can be clearly seen on the crushed surface that it has a high degree of porosity, from which the open pores and capillaries are significant on the surface. Based on the elemental composition determined by EDAX, the sample has a significant carbon and titanium at the surface, indicating that carbon and titan-containing surface layer has been formed during higher-temperature combustion. In the case of specimens with higher biological additive content, the surface of the pressed ceramic specimens was slightly nitrated. 
Based on the EDAX test, the specimen contains $45 \mathrm{~m} \% \mathrm{IG}-017$ has $1.51 \mathrm{~m} \%$ nitrogen content (Table 2).

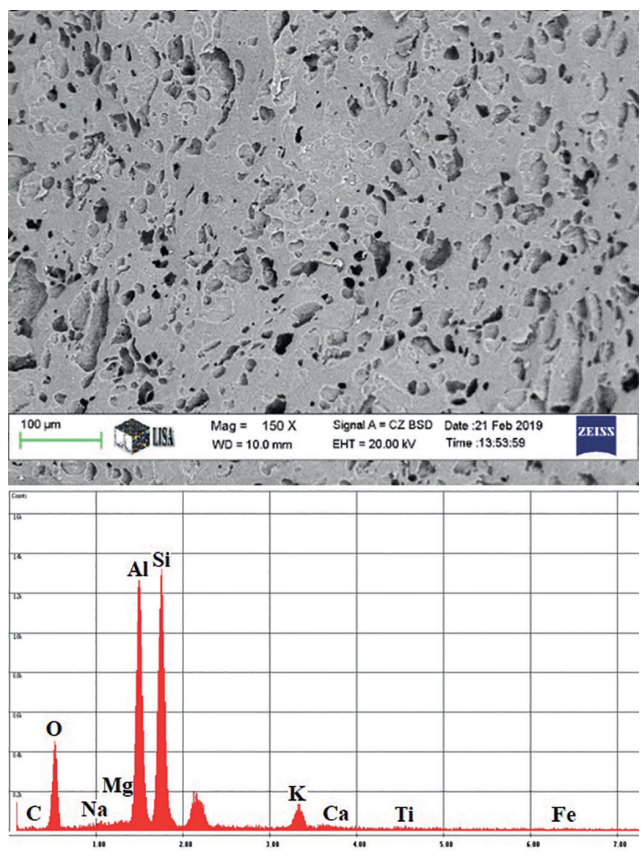

Fig $5 a$
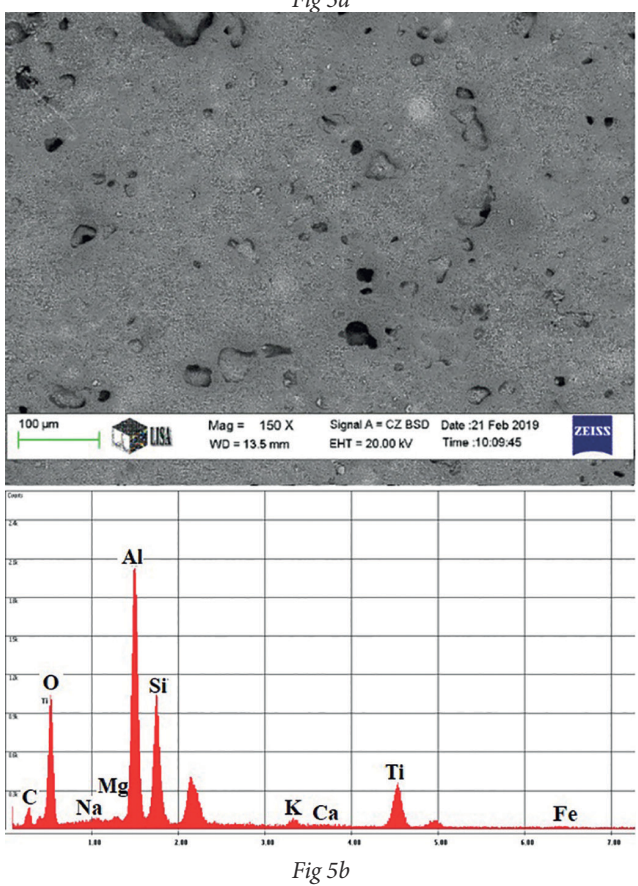

Fig. 5 The breaking surface (a) and outer surface (b) of the examined specimen from the I. mixture

5. ábra A I. keverékböl származó minta belsö, töretfelülete (a) és külső felülete (b)

The authors measured the oxide and phase composition of the sintered specimens with XRD test. After pre-sintering the specimens, the main phase was mullite with a large amount of amorphous glass phase and a small amount of quartz or cristobalite. During oxygen-free pre-sintering, carbon fibres were formed. After high-temperature heat treatment, the oxygen-free pre-sintered samples consisted of $60 \%$ mullite, $32 \%$ amorphous phase and $8 \%$ carbon fibres. Compared to the pre-sintered sample, the amount of carbon fibres in the sample was reduced (Table 3).
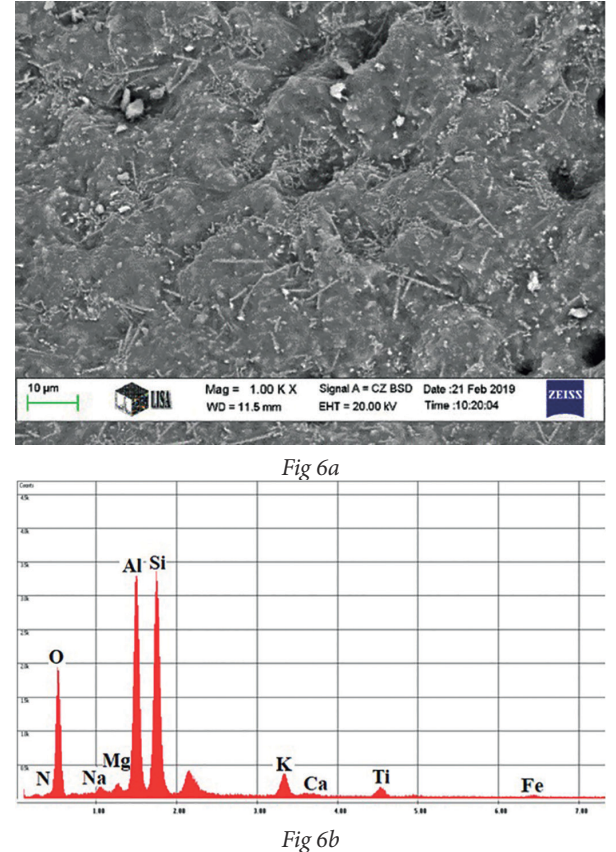

Fig. 6 The microstructure (a) and elemental composition (b) of the examined specimen from the IV. mixture

6. ábra A IV. keverékböl származó minta mikroszerkezete (a) és elemi összetétele (b)

\begin{tabular}{|c|c|c|c|c|}
\hline \multicolumn{2}{|c|}{$\begin{array}{c}\text { Mark of test specimen mixture } \\
\text { Location of EDAX test }\end{array}$} & \multicolumn{2}{|c|}{ I. } & $\begin{array}{l}\text { IV. } \\
\text { surface }\end{array}$ \\
\hline \multirow{10}{*}{ 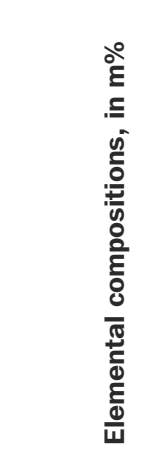 } & $\mathbf{N}$ & 0 & 0 & 1.51 \\
\hline & C & 1.88 & 11.61 & 0 \\
\hline & 0 & 24.00 & 32.81 & 31.81 \\
\hline & $\mathrm{Na}$ & 0.47 & 0.54 & 0.81 \\
\hline & Mg & 0.37 & 0.39 & 0.84 \\
\hline & Al & 26.28 & 24.70 & 23.30 \\
\hline & Si & 40.04 & 16.71 & 32.75 \\
\hline & K & 4.59 & 1.15 & 4.33 \\
\hline & $\mathrm{Ca}$ & 0.61 & 0.42 & 0.46 \\
\hline & $\mathrm{Ti}$ & 0.67 & 10.98 & 2.83 \\
\hline & $\mathrm{Fe}$ & 1.09 & 0.69 & 1.37 \\
\hline
\end{tabular}

Table 2 The elemental composition based on EDAX test 2. táblázat Az EDAX vizsgálat során kapott elemi összetétel

\begin{tabular}{|c|c|c|c|c|c|c|c|}
\hline $\begin{array}{l}\text { Sintered } \\
\text { atm. }\end{array}$ & $\begin{array}{c}\text { Phase } \\
\%\end{array}$ & SUM & $\begin{array}{l}\text { Mullite } \\
\mathrm{Al}_{6} \mathrm{Si}_{2} \mathrm{O}_{13}\end{array}$ & $\begin{array}{c}\text { Quartz } \\
\mathrm{SiO}_{2}\end{array}$ & $\begin{array}{c}\text { Cristo- } \\
\text { balite } \\
\mathrm{SiO}_{2}\end{array}$ & $\begin{array}{c}\text { Amorph } \\
\text { glass } \\
\mathrm{SiO}_{2}\end{array}$ & $\begin{array}{c}\text { Carbon } \\
\text { fiber } \\
\text { C }\end{array}$ \\
\hline \multirow{3}{*}{ Oxidation } & & 100 & 53 & 2 & 5 & 40 & 0 \\
\hline & $\mathrm{SiO}_{2}$ & 61.95 & 14.95 & 2 & 5 & 40 & \\
\hline & $\mathrm{Al}_{2} \mathrm{O}_{3}$ & 38.05 & 38.05 & & & & \\
\hline \multirow{4}{*}{$\begin{array}{l}\text { Oxygen- } \\
\text { free }\end{array}$} & & 100 & 48 & 4 & 1 & 32 & 15 \\
\hline & $\mathrm{SiO}_{2}$ & 50.54 & 13.54 & 4 & 1 & 32 & \\
\hline & $\mathrm{Al}_{2} \mathrm{O}_{3}$ & 34.46 & 34.46 & & & & \\
\hline & $\mathrm{CO}_{2}$ & 54.96 & & & & & 54.96 \\
\hline \multirow{4}{*}{$\begin{array}{l}\text { Nitrogen } \\
\text { gas } \\
\left(1600^{\circ} \mathrm{C}\right)\end{array}$} & & 100 & 60 & 0 & 0 & 32 & 8 \\
\hline & $\mathrm{SiO}_{2}$ & 48.92 & 16.92 & & & 32 & \\
\hline & $\mathrm{Al}_{2} \mathrm{O}_{3}$ & 43.08 & 43.08 & & & & \\
\hline & $\mathrm{CO}_{2}$ & 29.31 & & & & & 29.31 \\
\hline
\end{tabular}

Table 3 The oxide-and phase composition of the sintered specimens from IV mixture 3. táblázat AIV. keverékböl készült minta oxid-és fázisösszetétele 


\section{Conclusion}

In this research, the authors have successfully produced carbon-reinforced mullite ceramics using conventional kaolin minerals and IG-017 biological additive. Moreover, they continue their research on the production of mullite ceramics reinforced with silicon nitride particles or whiskers. Compared to the green products data, the weight loss and volume shrinkage of the prepared specimens after sintering at $1600^{\circ} \mathrm{C}$ were not influenced by the pre-sintering atmosphere. However, the elemental and phase composition of the final products are significantly influenced by the type of applied pre-sintering process. In the case of specimens with higher biological additive content, the surface of the pressed ceramic specimens was slightly nitrated.

\section{Acknowledgements}

The described article was carried out as part of the EFOP3.6.1-16-00011 "Younger and Renewing University Innovative Knowledge City - institutional development of the University of Miskolc aiming at intelligent specialization" project implemented in the framework of the Szechenyi 2020 program. The realization of this project is supported by the European Union, co-financed by the European Social Fund.

\section{References}

[1] Kalatur, E. S., Kozlova, A. V., Buyakova, S. P., Kulkov, S. N. (2013): Deformation behavior of zirconia-based porous ceramics, IOP Conf. Ser.: Mater. Sci. Eng., Vol. 47, 012004

https://doi.org/10.1088/1757-899X/47/1/012004

[2] Chu, H. L., Wang, C. L., Lee, H. E., Sie, Y. Y., Chen, R. S., Hwang, W. S., Wang, M. C. (2013): Effect of sintering process parameters on the properties of 3Y-PSZ ceramics, IOP Conf. Ser.: Mater. Sci. Eng., Vol. 47, 012005 https://doi.org/10.1088/1757-899X/47/1/012005

[3] Loca, D., Locs., J, Berzina-Cimdina, L. (2013): Preparation of hydroxyapatite/poly(lactic acid) hybrid microparticles for local drug delivery, IOP Conf. Ser.: Mater. Sci. Eng., Vol. 47, 012007 https://doi.org/10.1088/1757-899X/47/1/012007

[4] Mimira, T., Umeda, T., Musha, Y., Itatani, K. (2013): Properties of novel bone hemostat prepared using sugar-modified hydroxyapatite, phosphoryl oligosaccharides of calcium and thermoplastic resin, IOP Conf. Ser.: Mater. Sci. Eng., Vol. 47, 012008 https://doi.org/10.1088/1757-899X/47/1/012008

[5] Elek, J., Gömze, L. A. (2013): Scanning electron microscopic study of glass container degradation in infusion solution, IOP Conf. Ser.: Mater. Sci. Eng., Vol. 47, 012009 https://doi.org/10.1088/1757-899X/47/1/012009

[6] Rundans, M., Sperberga, I., Sedmale, G., Stinkulis, G. (2013): Effect of sintering process and additives on the properties of cordierite based ceramics, IOP Conf. Ser.: Mater. Sci. Eng., Vol. 47, 012012 https://doi.org/10.1088/1757-899X/47/1/012012

[7] Takato, M., Kaneko, M., Nishi, T., Saito, K., Uchikoba, F. (2013): Multilayer magnetic circuit for millimeter scale MEMS air turbine generator, IOP Conf. Ser.: Mater. Sci. Eng., Vol. 47, 012015 https://doi.org/10.1088/1757-899X/47/1/012015

[8] Kimura, T., Dong, Q., Yin, S., Hashimoto, T., Sasaki, A., Aisawa, S., Sato, T. (2013): Synthesis and piezoelectric properties of $\mathrm{Li}, \mathrm{Ca}$ and $\mathrm{Mn}-$ codoped BaTiO3 by a solvothermal approach, IOP Conf. Ser.: Mater. Sci. Eng. Vol. 47, 012018 https://doi.org/10.1088/1757-899X/47/1/012018

[9] Pura, A., Locs, J., Berzina-Cimdina, L. (2013): The effect of thermal processing parameters on the microstructure of extruded and sintered TiO2 ceramics, IOP Conf. Ser.: Mater. Sci. Eng., Vol. 47, 012019 https://doi.org/10.1088/1757-899X/47/1/012019
[10] Dedova, E., Klevtsova, E., et al 2013 IOP Conf. Ser.: Mater. Sci. Eng. ,Vol. 47, 012021 https://doi.org/10.1088/1757-899X/47/1/012021

[11] Abe, K., Hamada, J., Miyazawa, M., Kuwahara, H., Itatani, K. (2013): Fabrication of transparent sintered $\mathrm{ZnO}-\mathrm{B} 2 \mathrm{O} 3-\mathrm{Bi} 2 \mathrm{O} 3$ glass body by pressureless firing and hot isostatic pressing, IOP Conf. Ser.: Mater. Sci. Eng. ,Vol. 47, 012024 https://doi.org/10.1088/1757-899X/47/1/012024

[12] Sidelnikova, O. N., Pozdnyakov, G. A., Salanov, A. N. (2013): Light scattering glass material modified by the surface ion exchange for the energy efficient using in the technical and decorative lighting, IOP Conf. Ser.: Mater. Sci. Eng., Vol. 47, 012026 https://doi.org/10.1088/1757-899X/47/1/012026

[13] Kotov, L. N., Turkov, V. K., Vlasov, V. S., Lasek, M. P., Kalinin, Yu E., Sitnikov, A. V. (2013): Conductive, magnetic and structural properties of multilayer films, IOP Conf. Ser.: Mater. Sci. Eng., Vol. 47, 012027 https://doi.org/10.1088/1757-899X/47/1/012027

[14] Gömze, L. A., Gömze, L. N., Egész, Á., Ojima, F. (2013): High Porosity Alumina as Matrix Material for Composites of AlMg Alloys, IOP Conf. Ser.: Mater. Sci. Eng. Vol. 47, 012030 https://doi.org/10.1088/1757-899X/47/1/012030

[15] Ibrahim, J. F. M., Mergen, A. (2015): Enhancement of structural and magnetic properties of $\mathrm{Eu}$ and $\mathrm{Fe}$ doped $\mathrm{GdMnO} 3$ and $\mathrm{Cr}$ doped HoMnO3 multiferroic ceramics, Diss. Marmara University, https://doi.org/10.13140/RG.2.2.32693.32486

[16] Baideldonova, A., Ksandopulo, G., Mukhina, L. (2016): Initiation of the Adiabatic Wave of Combustion for Obtaining the Substances with the Free Valence, IOP Conf. Ser.: Mater. Sci. Eng. Vol. 123, 012032 https://doi.org/10.1088/1757-899X/123/1/012032

[17] Kolmakova, T. V., Buyakova, S. P., Kulkov, S. N. (2016): Researches of mechanical behavior of bone tissues for development and selection of individual ceramic implants, IOP Conf. Ser.: Mater. Sci. Eng. Vol. 123, 012005 https://doi.org/10.1088/1757-899X/123/1/012005

[18] Kotov, L., Ustyugov, V., Vlasov, V., Turkov, V., Lasek, M., Kalinin, Yu, Sitnikov, A., Golubev, E. (2016): The particle size distribution function in the composite films and microwave magnetic properties, IOP Conf. Ser.: Mater. Sci. Eng. Vol. 123, 012009 https://doi.org/10.1088/1757-899X/123/1/012009

[19] Saidi, M and Safi, B (2016): Effect of mineral additives (natural pozzolana and sand of dunes) by substitution of cement on the performance and durability of mortars, IOP Conf. Ser.: Mater. Sci. Eng. Vol. 123, 012015 https://doi.org/10.1088/1757-899X/123/1/012015

[20] Gostev, V. A., Pitukhin, E. A., Ustinov, A. S., Shelestov, A. S. (2016): Thermal Insulation Properties Research of the Composite Material "Water Glass - Graphite Microparticles” IOP Conf. Ser.: Mater. Sci. Eng. Vol. 123, 012018 https://doi.org/10.1088/1757-899X/123/1/012018

[21] Kotova, O., Ozhogina, E., Ponaryadov, A., Golubeva, I. (2016): Titanium minerals for new materials, IOP Conf. Ser.: Mater. Sci. Eng. Vol. 123, 012025 https://doi.org/10.1088/1757-899X/123/1/012025

[22] Kováŕík, T., Kullová, L., Rieger, D. (2016): Production of refractory chamotte particle-reinforced geopolymer composite, IOP Conf. Ser: Mater. Sci. Eng. Vol. 123, 012041 https://doi.org/10.1088/1757-899X/123/1/012041

[23] Rundans, M., Sperberga, I., Sedmale, G. (2016): Porous and Dense Cordierite Ceramic from Illite Clay, IOP Conf. Ser.: Mater. Sci. Eng. Vol. 123, 012042 https://doi.org/10.1088/1757-899X/123/1/012042

[24] Lakatos, J. and Snape, C. E. (2017): High capacity MnOx:ZrO2 sorbent for elementary mercury capture: preparation, characterization and comparison to other sorbents, IOP Conf. Ser.: Mater. Sci. Eng. Vol. 175, 012032 https://doi.org/10.1088/1757-899X/175/1/012032

[25] Chuklina, S. G., Malenkova, S. A., Pylinina, A. I., Podzorova, L. I., Ilyicheva, A. A. (2017): Effect of composition and calcination temperature of ceria-zirconia-alumina mixed oxides on catalytic performances of ethanol conversion IOP Conf. Ser.: Mater. Sci. Eng. Vol. 175, 012031 https://doi.org/10.1088/1757-899X/175/1/012031

[26] Buzimov, A. Y., Kulkov, S. N., Kurovics, E., Eckl, W., Pappert, S. (2017): Influence of mechanical activation on the properties of natural zeolites from Tokaj Mountain, IOP Conf. Ser.: Mater. Sci. Eng. Vol. 175, 012033 https://doi.org/10.1088/1757-899X/175/1/012033

[27] Ibrahim, J. F. M., Mergen, A., İlhan Sahin, E., (2018): The effect of 
europium doping on the structural and magnetic properties of $\mathrm{GdMnO} 3$ multiferroic ceramics, Advanced Ceramics Progres, Vol. 3, No. 4, pp. 1-5

[28] Grigoriev, M. V., Savchenko, N. L., Sablina, T. Yu., Kurovics, E., Sevostyanova, I. N., Buyakova, S. P., Gömze, L. A., Kulkov, S. N. (2018): Deformation and fracture of alumina ceramics with hierarchical porosity, Építőanyag - JSBCM, Vol. 70, No. 1, pp. 18-22 https://doi.org/10.14382/epitoanyag-jsbcm.2018.4

[29] Knyazeva, A. G., Pribytkov, G. A., Chumakov, Yu. A. (2018): Titaniumbased composite synthesis in the combustion regime, Építőanyag - JSBCM, Vol. 70, No. 3, pp. 74-77 https://doi.org/10.14382/epitoanyag-jsbcm.2018.13

[30] Olt, J., Maksarov, V. V., Keksin, A. I. (2018): Internal thread cutting process improvement based on cutting tools treatment by composite powders in a magnetic field, Építőanyag - JSBCM, Vol. 70, No. 4, pp. 128-131 https://doi.org/10.14382/epitoanyag-jsbcm.2018.24

[31] Baba, S., Goto, T., Cho, S., Sekino, T. (2018): Microstructure and mechanical properties of TiN dispersed Si3 N4 ceramics via in-situ nitridation of coarse metallic Ti, Építőanyag - JSBCM, Vol. 70, No. 6, pp. 195-203 https://doi.org/10.14382/epitoanyag-jsbcm.2018.34

[32] Abed, M., Nemes, R. (2019): Fresh properties of the selfcompacting high-performance concrete using recycled concrete aggregate, Építőanyag - JSBCM, vol. 71, no. 1, pp. 18-23 https://doi.org/10.14382/epitoanyag-jsbcm.2019.4

[33] El-Fakharany, M. E., Ezzat, M., Gad, A., Ghafour, N. G. Abdel, Baghdady, A. R. (2019): Performance of dolomitic cementitious mortars as a repairing material for normal concrete in Egypt, Építőanyag - JSBCM vol. 71, no. 2, pp. 33-42 https://doi.org/10.14382/epitoanyag-jsbcm.2019.7

[34] Ibrahim, J. F. M., Kurovics, E. and Gömze, L. A. (2019): Synthesis, characterization and rheological properties of alumina-zeolite mixtures, MultiScience - XXXIII. microCAD International Multidisciplinary Scientific Conference, Hungary, http://dx.doi.org/10.26649/musci.2019.076

[35] Kulkov, S. and Savchenko, N. (2008): Wear behavior of zirconia-based ceramics under high-speed dry sliding on steel, Építőanyag - JSBCM, vol. 60 , no. 3 , p. 62 http://dx.doi.org/10.14382/epitoanyag-jsbcm.2008.10

[36] Lukin, E. S., Makarov, N. A., Kozlov, A. I., Popova, N. A., Anufrieva, E. V., Vartanyan, M. A., Kozlov, Yu. A., Safina, M. N., Lemeshev, D. O., Gorelik, E. I. (2008): Oxide ceramics of the new generation and areas of application, Glass and Ceramics, vol. 65, no. 9-10, pp. 348-352. Translated from Steklo i Keramika no. 10 pp. 27-31, October, 2008

[37] Ershova, N. I. and Kelina, I. Y. (2009): High-temperature wear-resistant materials based on silicon nitride Építőanyag - JSBCM, vol. 61, no. 2, p. 34 http://dx.doi.org/10.14382/epitoanyag-jsbcm.2009.6

[38] Gömze A. L. and Gömze, N. L. (2009): Alumina-based heteromodulus ceramic composites with extreme dynamic strength - phase transformation of Si3N4 during high speed collisions with metallic bodies, Építőanyag - JSBCM, vol. 61, no. 2, p. 38 http://dx.doi.org/10.14382/epitoanyag-jsbcm.2009.7

[39] Rocha-Rangel, E., Hernández-Silva, D., Terés-Rojas, E., Martines-Franco, E. and Diaz-De La Torre, S. (2010): Aluminabased composites strengthened with titanium and titanium carbide dispersions, Építőanyag - JSBCM, vol. 62, no. 3, p. 75 http://dx.doi.org/10.14382/epitoanyag-jsbcm.2010.15

[40] Gömze A. L. and Gömze, N. L. (2011): Hetero-modulus alumina matrix nanoceramics and CMCs with extreme dynamic strength" IOP Conf. Ser.: Mater. Sci. Eng., vol. 18, p. 082001 http://dx.doi.org/10.1088/1757-899X/18/8/082001

[41] Yu, C., Deng, C., Yuan, W. and Zhu, H. (2013): The Effect of Adding TiO 2 on Synthesisof $\mathrm{Al}_{4} \mathrm{SiC}_{4}$ powders"IOPConf.Ser.:Mater.Sci.Eng.,vol.47,p.012059 http://dx.doi.org/10.1088/1757-899X/47/1/012059

[42] Li, J., Yuan, W. J., Deng, C. J. and Zhu, H. X. (2013): The Effect of $\mathrm{Si}$ contents on the reaction-bonded $\mathrm{Si}_{3} \mathrm{~N}_{4} / \mathrm{SiC}$ composite ceramics" IOP Conf. Ser.: Mater. Sci. Eng., vol. 47, p. 012060 http://dx.doi.org/10.1088/1757-899X/47/1/012060

[43] Vereschaka, A., Kutin, A., Sitnikov, N., Oganyan, G., Sharipov, O. (2016): Research of mechanical and cutting properties, wear and failure mechanisms of nanostructured multilayered composite coating
Ti-TiN-(NbZrAl)N, Építőanyag - JSBCM, vol. 68, no. 3, p. 114 http://dx.doi.org/10.14382/epitoanyag-jsbcm.2016.20

[44] Tariq, F., Rafique, U., Yaqoob, K. (2017): Synthesis of aluminosilicates functionalized titanium as potential adsorbent: An industrial possibility" Építőanyag - JSBCM, vol. 69, no. 3, p. 94 https://doi.org/10.14382/epitoanyag-jsbcm.2017.16

[45] Kurovics, E., Shmakova, A., Kanev, B. and Gömze, L. A. (2017): Development ceramic composites based on $\mathrm{Al}_{2} \mathrm{O}_{3}, \mathrm{SiO}_{2}$ and IG017 additive, IOP Conf. Ser.: Mat. Sci. Eng., vol. 175, p. 012013 http://dx.doi.org/10.1088/1757-899X/175/1/012013

[46] Gömze, L. A., Kulkov, S. N., Kurovics, E., Buyakov, A. S., Buzimov, A. Y., Grigoriev, M. V., Kanev, B. I., Kolmakova, T. V., Levkov, R. V., Sitkevich, S. A. (2018): Development ceramic floor tiles with increased shear and pressure strengths, Építőanyag - JSBCM, vol. 70, no. 1, p. 13, https://doi.org/10.14382/epitoanyag-jsbcm.2018.3

[47] Bobkova, N. M. (2007): Fizicheskaya Himiya Tugoplavkih Nemetallicheskih i Silicatnyh Materialov, Yvyshej Shaya, Minszk, pp.8890 [E-book] ISBN 978-985-06-1389-9

[48] Gömze, A. L., Liszátzné Helvei, Á., Simonné Odler, A., Szabó, M. (2001): Ceramic yearbook I. 2001, ÉTK and MÉASZ, Budapest, ISBN 963512774 X pp.30-85

[49] Varga, G. (2007): The structure of kaolinite and metakaolinite, Építőanyag - JSBCM, vol. 59, no. 1, p. 6, 2007 http://dx.doi.org/10.14382/epitoanyag-jsbcm.2007.2

[50] Duval, D. J., Risbud, S. H., Shackelford, J. F. (2008): "Mullite” in Ceramic and Glass Materials, Shackelford, J., Doremus, R. H., Ed. Springer, pp. 2739 http://www.springer.com/978-0-387-73361-6

[51] Gömze, A. L. and Gömze, N. L. (2013): Ceramic based lightweight composites with extreme dynamic strength, IOP Conf. Ser.: Mater. Sci. Eng., vol 47. p. 012033, 2013 https://doi.org/10.1088/1757-899X/47/1/012033

[52] Riedel, Ralf (2008): Handbook of Ceramic Hard Materials, 2008 https://doi.org/10.1002/9783527618217

[53] Carter, C. Barry, Norton, M. Grant (2013): Ceramic Materials Science and Engineering Springer, p.674 ISBN 978-1-4614-3523-5

Hampshire, Stuart (2009): Silicon Nitride Ceramics, Materials Science Forum, Vol. 606, pp. 27-41

[54] Mackenzie, K. J. D., Meinhold, R. H., White, G. V., Sheppard, C. M., Sherriff, B. L. (1994): Carbothermal Formation of $\beta$-Sialon from Kaolinite and Halloysite Studied by Si-29 and Al-27 Solid-State MAS NMR, Journal of Materials Science 29 http://doi.org/10.1007/BF00356808

[55] Cho, Y. W. and Charles, J. A. (1991): Synthesis of nitrogen ceramic powders by carbothermal reduction and nitridation, Materials Science and Technology, Vol. 7 pp. 399-406

[56] Kurovics, E., Gömze L. A. (2017): Development of high-tech ceramic composites from conventional kaolinite minerals and IG-017 additives, MultiScience - XXXI. microCAD International Multidisciplinary Scientific Conference, Hungary, http://doi.org/10.26649/musci.2017.030

$\underline{\text { Ref.: }}$

Kurovics, Emese - Kotova, Olga B. - Gömze, László A .- Shushkov, Dmitry A. - Ignatiev, Grigoriy V. - Sitnikov, Petr A. - Ryabkov, Yuri I. - Vaseneva, Irina N. - Gömze, Ludmila N.: Preparation of particle-reinforced mullite composite ceramic materials using kaolin and IG-017 bio-origin additives

Építőanyag - Journal of Silicate Based and Composite Materials, Vol. 71, No. 4 (2019), 114-119. p. https://doi.org/10.14382/epitoanyag-jsbcm.2019.20 